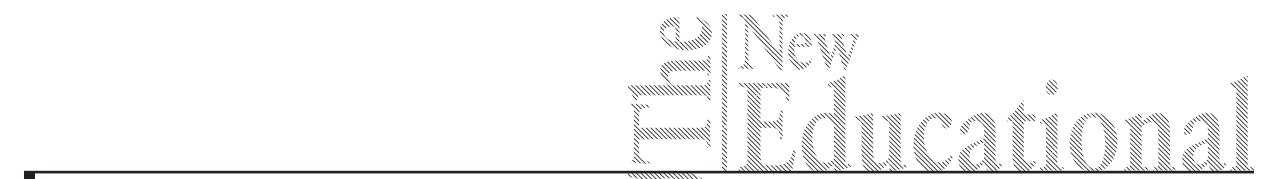

Yunus Emre Karakaya, Sebahattin Dovecioglu

USA

Hasan Huseyin Kilinc

Turkey

\title{
Teachers' Behaviors towards Mentally Disabled Students in Physical Education Classes
}

DOI: $10.15804 /$ tner.2015.40.2.20

\begin{abstract}
The goal of this research was to examine the verbal and non-verbal behaviors of teachers towards mentally disabled students in physical education classes in Special Education Practice Centers (Schools for Mentally Disabled Students) in Turkey. The study was based on qualitative research and data was collected through interview forms prepared by the researchers. The interviews consisted of four semi-structured questions, which were analyzed by using the method of content analysis and qualitative data analysis software. Accordingly, it was observed that teachers used a variety of mimics and gestures as reflections of their body language in order to establish and control class management. The teachers interviewed stated that they consciously used their specific way of posture, walking and sitting in the classroom. They also stated that they frequently changed their positions in the classroom and embraced a variety of distance and touch behaviors towards the mentally disabled students. In conclusion, these teachers have the greatest responsibility to achieve the goals of physical education class for the mentally disabled students. These responsibilities are crucial for the educational advancement of the mentally disabled students. The non-verbal behaviors and expressions of these teachers play a vital role in the mental and behavioral development of the mentally disabled students.
\end{abstract}

Keywords: mentally disabled students, teachers, physical education class, classroom management, teacher behaviors

\section{Introduction}

Today, more emphasis is given on teachers' class management skills and their advancement rather than the problems related to students' misconduct in the classroom (Wragg and Wragg, 1998). For instance, Selçuk (2001: 64) suggests that 
it is more important for teachers to consider whether students are aware of the behaviors expected from them, especially those students who misbehave in the classroom. Class management is a multi-dimensional task and it entails a longterm commitment. Good management of the class is considered as a precondition for a successful teacher (Demirel, 2000; Balk1, 2003). The teachers who are incompetent in class management are most likely to be less successful in teaching activities (Celep, 2002).

If an individual shows a qualitative difference from his/her peers in terms of personal characteristics and education qualifications, he/she entails a special education (Milli Eğitim Bakanlığı, 2002). In Turkey, Special Education Practice Centers are institutions for mentally disabled students who cannot benefit from general education programs. These institutions are mostly focused on education programs dealing with basic life skills and functional academic skills (Sucuoğlu, 2010: 44). The goal of these special education programs for the mentally disabled is to educate them toward daily living practices without being dependent on others (Karabulut and Yıkmış, 2010: 104). Mentally disabled individuals aspire for skill sets of independent living in the public sphere. The realization of these goals depends on the education programs that they attend and the presentation of contextualized methods and approaches (Özyürek, 1990; Gürsel, 1993).

In this context, it is likely that teachers would have difficulties in communication with mentally disabled students and thus it is vital to take the nature of educational methods and approaches into account. For this reason, the ways teachers behave and the ways they talk to mentally disabled students are crucial in the classroom. Overall, the goal of this research was to examine and determine the non-verbal behaviors and verbal expressions of teachers toward mentally disabled students in physical education classes in Turkey's Education Practice Centers. The results of this research are likely to be instructive for the development of teaching practices in these instutions in terms of increasing the physical education teachers' awareness of their verbal and non-verbal behaviors toward mentally disabled students.

\section{Research Methodology}

As this study adopted the qualitative research method, the research design particularly relied on a case study approach. Yıldırım ve Şimşek (2006) defined case studies as a qualitative research design that thoroughly and deeply investigates a specific case or cases. For sample selection, "convenience sampling" was used. The sample of this research included 45 teachers who work in Special Education 
Practice Centers (schools) in the cities of Elazig (11 teachers), Adana (7 teachers), Cankırı (5 teachers), Amasya (7 teachers), Siirt (6 teachers), and Gaziantep (9 teachers). The sample demographic and occupational characteristics are as follows: 26 male teachers and 19 female teachers; 26 teachers with an undergraduate degrees and 14 teachers with a graduate degrees; 22 teachers have occupational experience between $0-5$ years, 13 teachers between $6-10$ years, and 10 teachers between 11-15 years. Finally, according to the service experience in these special education institutions, 35 teachers have experience of $0-5$ years and 10 teachers have experience between 6-10 years.

The data was collected through semi-structured interviews and these interviews consisted of four questions. The aim of these questions was to reveal the teachers' thoughts on their non-verbal behaviors and verbal expressions in the classroom. The interview questions are listed below:

- What kind of mimics and gestures as reflections of your body language do you use in your physical education class in order to manage the class?

- Do you intentionally use your way of posture, walking, and sitting in order to manage your physical education class?

- Do you use behaviors of distance and physical contact (touch) in order to manage your physical education class? If you do, what kind of student behaviors do you use them as a response or reaction to?

- What kind of verbal expressions do you use in order to manage your physical education class? Please provide examples.

A study by Baş (2010) was used in the process of preparing the interview questions. The validity of the content and the interview form were formed by consulting the faculty members of educational sciences $(n=3)$, who are specialists in their fields. The teachers' participation was voluntary. Yıldırım and Şimşek (2006) explain that this is important in terms of establishing the validity and reliability of research. The interviews with the sample group were conducted in the teachers; offices in their institutions and one interview took between 5 to 15 minutes. Together with audio recording of the interviews, note taking was also preferred to analyze the interview data. After the completion of the interviews, analysis of the obtained data was made with qualitative content analysis process. The teachers' views in the interviews were taken without revision while parsing the interview data.

The interviewees' views were encoded as Teacher 1 Female (T1F), Teacher 2 Male $(T 2 M) \ldots$ and the data was transferred to the computer. In data analysis, computer aided qualitative-data analysis was used. In this context, content analysis was conducted. The content analysis was conducted with the identification of findings and 
interpretation, codes and the arrangement of the theme, the presence of the theme, and coding of data (Yıldırım ve Şimşek: 2006). That data analysis and modeling of the situation were carried out with the use of QSR NVIVO-8 program (Figure 1, 2,3 and 4). Moreover, some of the important remarks of the interviewees are given in the findings section below.

\section{Research Results}

The interview results are modelled and discussed below.

\section{The Views of the Interviewed Teachers on Their Use of Mimics and Gestures In Managing the Classroom}

As stated above, the first question in the interview process was: What kind of mimics and gestures as reflections of your body language do you use in your physical education class in order to manage the classroom? Answers to this question and their frequency numbers are thematically organized in the model shown below (Figure 1).

Figure 1. Model Based on the Teachers' Mimics and Gestures

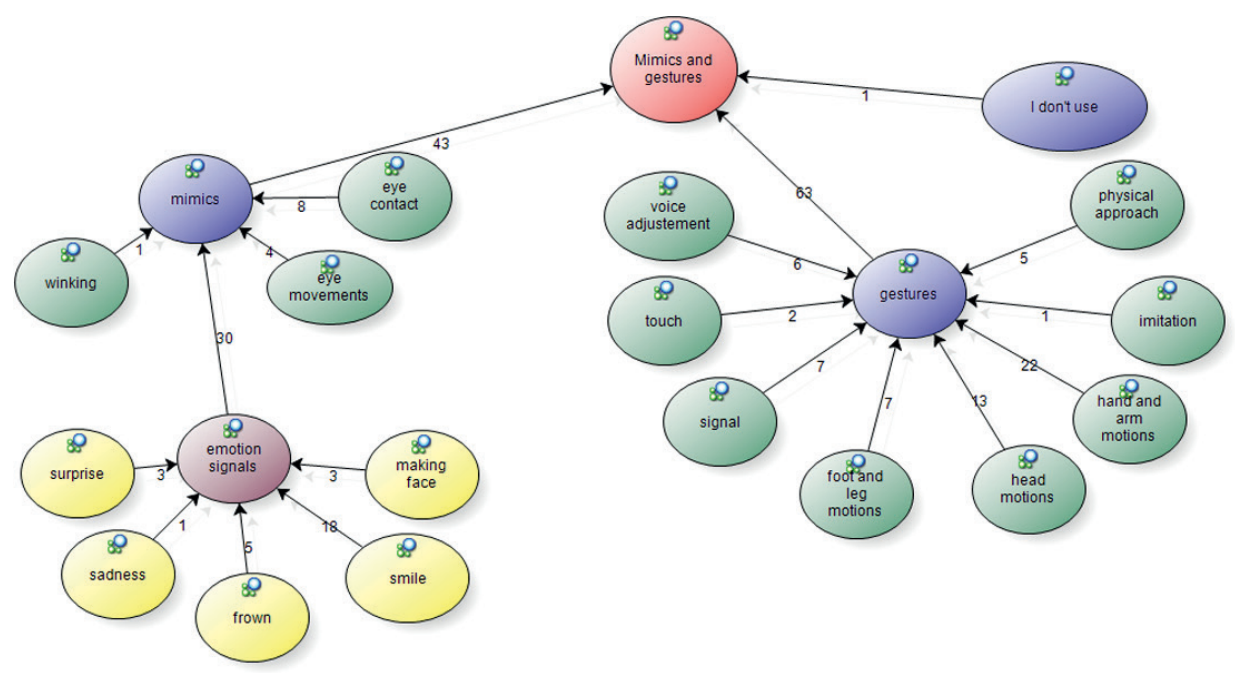

As shown in Figure 1, the teachers' mimics and gestures for managing the class show differences. Based on the teachers' responses in the interviews, a variety of mimics is used such as "making eye contact," "eye movements," "winking," and 
"emotion signals." Examples of "emotion signals," include the mimics of "smile," "frown," "making a face," "surprise," and "sadness." In addition, the gestures used by the teachers interviewed include "hand and arm motions," "head motions," "foot and leg motions," "signal," "voice adjustment," "physical approach," "touching," and "imitation." One of the teachers interviewed stated that s/he did not use any mimic or gesture in class management. According to this research, it is safe to state that many teachers tend to use mimics and gestures in class management. Some of the responses by the teachers interviewed are presented below:

T-3 F: In class management, I frequently use mimics and gestures towards the mentally disabled students. I think these are effective in reducing the negative behaviors of the students. Yet, these mimics and gestures are not sufficient themselves to establish positive behavioral conduct for the mentally disabled students.

T-6 M: I try to use mimics and gestures in a way that the mentally disabled students can perceive physically, emotinally, socially, behaviorally, and visually.

\section{The Views of the Teachers on Their Intentional Use of Their Way of Posture, Walking, and Sitting}

In this context, as stated above, the interviewees were asked the following question: Do you intentionally use your way of posture, walking, and sitting in order to manage your physical education class? Answers to this question and their frequency numbers are thematically organized in the model shown below (Figure 2).

Figure 2. Model Based on the Teachers' Intentional Use of Posture, Walking, Sitting

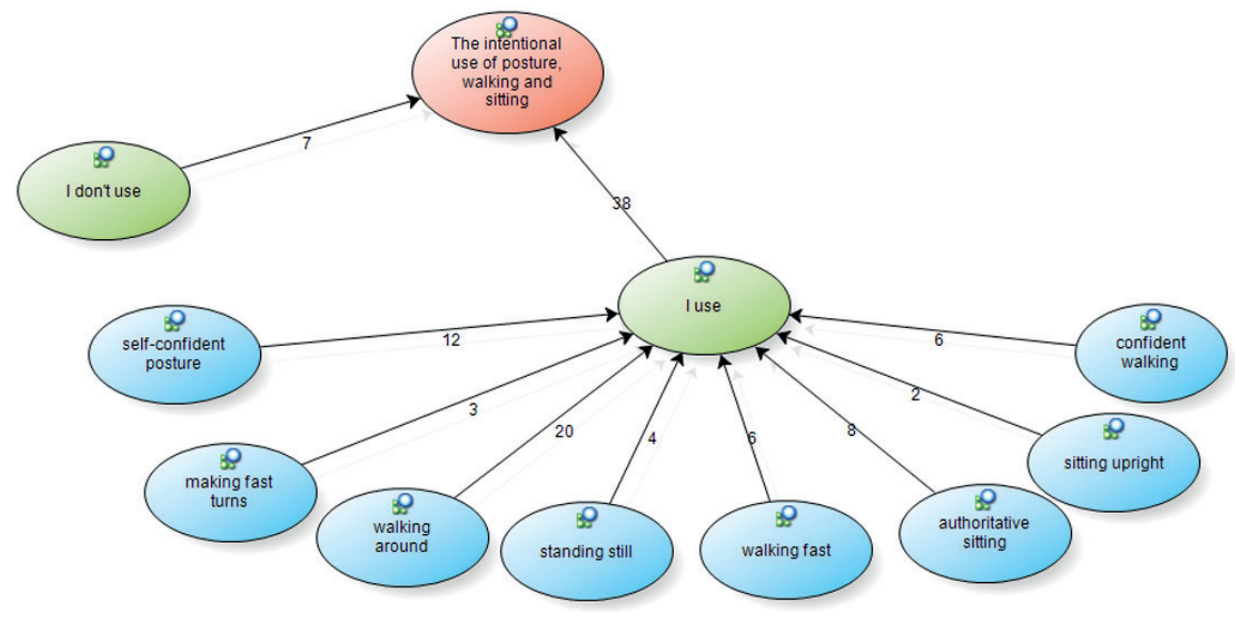


As shown in Figure 2, the teachers' responses show differences. Only 7 of the teachers interviewed indicated that they had no intentional interest in functionally using their way of walking, posture, and sitting in their class management. On the other hand, the responses of those who stated that they intentinally use these behaviors in the classroom include "walking around the students," "giving a self-confident posture," "authoritative sitting," "confident walking," "walking fast," "standing still," "making fast turns," and "sitting upright." According to these responses, it can be stated that the teachers consider walking around students and making self-confident movements as the most efficient class management. Some of the responses by the teachers interviewed are presented below:

T-42 F: Yes, I pay attention to my way of walking and posture in the classroom because the students can adopt these for themselves. Since they can adopt any of my mistaken movement, I have to be careful on this subject.

T-45 F: I intentionally use my way of walking, posture and sitting. For instance, I make sudden turns and carefully raise my voice in the sports hall in order to get their attention.

\section{The Teachers' Views on the Behaviors of Space, Distance, and Touch for the Management of the Physical Education Class}

As stated above, the teachers were asked: Do you use behaviors of distance and physical contact (touch) in order to manage your physical education class? If you do, what kind of student behaviors do you use them as s response or reaction to? Answers to this question and their frequency numbers are thematically organized in the model shown below (Figure 3).

As shown in Figure 3, the teachers' views show differences in terms of space, distance, and touch (pyhsical contact) behaviors in the classroom. Two of the teachers stated that they did not get involved in such behaviors. On the other hand, those who stated that they funtionally used space, distance, and touch aspects in the classroom resort to these behaviors "to increase class participation," "when students misbehaved," "to increase the attention to the subject," "when class order is disrupted," "to control the classroom," "based on the activity," "to give reinforcment," "based on the class content," and "based on the approach of the student." Accordingly, it seems that the teachers mostly resort to the behaviors of space, distance, and touch to increase class participation, on the one hand, and when students misbehave in the classroom, on the other. Some of the responses by the teachers interviewed are presented below:

T-1 F: In physical education classes, I try to become closer to the students when class order is disrupted. I try to change my position along with the positions of the students. 
Figure 3. Model Based on Teachers' Space, Distance, and Touch (pyhsical contact) Behaviors

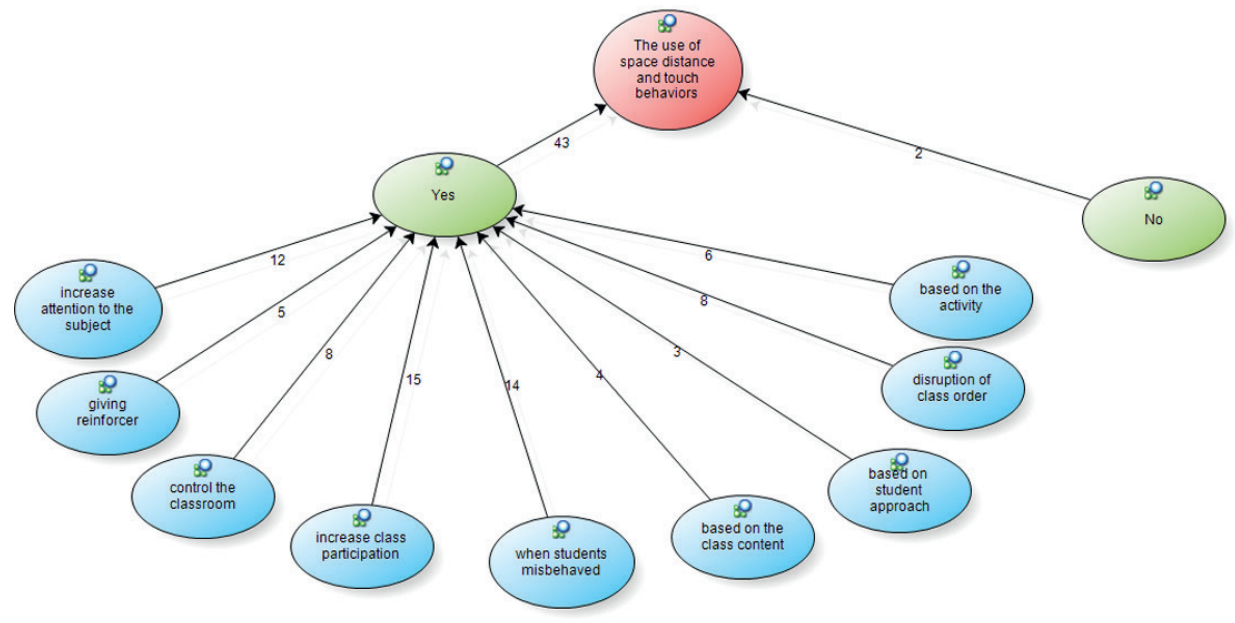

T-43 M: I use touch behavior toward the students. When student misbehavior occurs in the classroom, I change my position properly and accordingly.

4. The Teachers' Views on Their Verbal Expressions in Their Interactions with the Students for Managing the Physical Education Class

The last question in the interviews, as stated above, was: What kind of verbal expressions do you use in order to manage your physical education class? Answers to this question and their frequency numbers are thematically organized in the model shown below (Figure 4).

As shown in Figure 4, there are differences in the teachers' views regarding the verbal expressions they use in class. In terms of class management, these verbal expressions include "advisory statements," "addressing the students by their name,"'encouraging statements," "affectionate expressions," "statement of the rules," "warning," "positive reinforcement," and "orders." It seems that the teachers mostly use advisory statements, addressing the students by their name and encouraging statements in the management of the class. Some of the responses by the teachers interviewed are presented below:

T-15 M: In my physical education class, I mostly use affectionate expressions to my students such as dear and darling. In addition, I encourage them by expressions such as "you are very athletic." 
Figure 4. Model Based on Verbal Expressions Used in Class Management

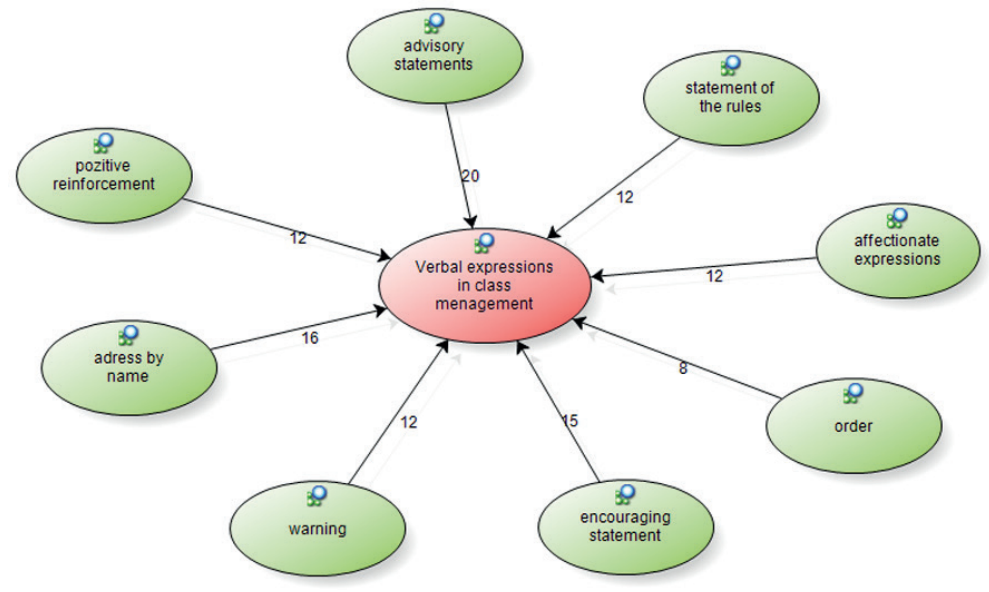

T-22 M: During the class, I usually make statements such as: "Listen to me carefully. If you rightly do what I show you, I will let you play the educational games that you like in the last 15 minutes of the class."

\section{Conclusions}

In this section, the data presented in the findings section is discussed in relation to the existing literature and policy recommendations are suggested. The teachers' mimics and gestures in their interactions with the mentally disabled students for managing the physical education class have shown differences (Figure 1). These mimics and gestures seem to be used by the teachers frequently, whenever they consider them necessary in managing their physical education classes. In the interviews, the eachers stated that they mostly used eye contact and emotion signals in terms of their mimics in class. Among the gestures, hand and arm motions are the most frequent non-verbal expressions of the teachers. The reason for the use of these mimics and gestures is that they create a positive interaction and relationship between the teacher and the students. According to Baş (2010: 24), the teacher's body posture, walking style, and facial expressions directly affect and shape the perceptions of the students in the starting periods of classes. These examples of body language also provide feedback for teachers of how class activites are performed. For instance, according to Ertuğrul (2002: 165), many explanations 
are given via eyes and they are perceived via eyes as well. Students' reactions and impressions in subjects lectured in class can be perceived by the way they look at the teacher. If there are positive reactions in the eyes, faces, and behaviors of the students during the lecture, it means that they are interested in the subject and this leads to positive reactions in their psyche. For this reason, the teacher needs to carefully observe and evaluate the process of his/her interaction with students and the meaning of their body language and reactions (Çalışkan and Yeşil: 2005: 206). In a study by Pektaş (1988), it is shown that non-verbal communication of teachers with their students such as by hand and arm motions and facial expressions has positive effects on education in general and the learning process in particular. Yet, as Çalışkan (2003) argues in his study on teachers' non-verbal communication, mimics and gestures are not sufficiently used by teachers. Moreover, he argues that senior and female teachers are more efficient in using mimics and gestures.

The responses from the teachers interviewed show differences in terms of their intentional interest in functionally using their way of walking, posture, and sitting in class management (Figure 2). According to these responses, the teachers consider walking around students and making self-confident movements as the most efficient class management. On the other hand, some teachers interviewed indicated that they had no intentional interest in functionally using their way of walking, posture, and sitting in their class management. The reason for this choice seems to be the lack of knowledge of efficient class management and in efficient communication with mentally disabled students. According to Çalışkan and Yeşil (2005: 205), communcation and interaction with students are very important for teachers and the teacher needs to examine his/her behaviors carefully as well as students' reactions. Teachers can use their body postures and positions to show students their presence and command in the classroom. Teachers also need to be energetic in class rather than showing signs of tiredness or exhaustion because behavioral education is more contributory to individual development than advisory education in the teaching-learning processes. For instance, Erden (2005: 98) states that self-confident teachers who are approachable and have a sense of humor lead to a positive classroom environment and teacher-student relationship.

The views of the teachers show differences in terms of space, distance, and touch (pyhsical contact) behaviors in the classroom (Figure 3). The teachers mostly resort to these behaviors of space, distance, and touch to increase class participation, on the one hand, and when students misbehave in the classroom, on the other. According to Schober (1999: 120), the position of the teacher in class affects the process of communication and interaction with the students. Behaviors and appearance in addition to knowledge are likely to improve the sense of authority 
in class. Teachers need to see the whole classroom from a two-meter distance and make students appeal to positive behaviors. For instance, Ertuğrul (2002: 64) states that teachers need to adjust and readjust their distance from students as an instrument of transmitting non-verbal messages in class. All students should be seen from the position of the teacher. Moreover, Erden (2005: 98) argues that teachers' posture style and their way of touching students may enhance a positive teacher-student relationship.

There are differences in the teachers' views regarding the verbal expressions they use in class (Figure 4). The teachers interviewed stated that they mostly use advisory statements, addressing students by their name and encouraging statements in the management of the class. In this process, effective class management is crucial to develop a fruitful teaching-learning environment and communication mechanisms. For this purpose, teachers need to be able to change students' negative behaviors, establish rules, communicate robustly and manage time efficiently. The role of the teacher in creating a positive classroom atmosphere depends on his/her efficient and robust class management. This, in turn, is likely to improve student success and positive approach to schooling and education (Norris, 2003: 313-318; Marzano and Marzano, 2003: 6-13; Çelik, 2002; Aydın, 2000). While some teachers tend to design fun and enjoyable class management, others might be strictly disciplinary. In fact, the education that teachers have gone through themselves is the most important factor in their verbal expressions in class. The teacher's approach to class management, the way he/she lectures and the content of the lecture are some signs of the structure of the class adopted by that teacher (Baş, 2010: 45). According to Celep (2002: 161), the teacher needs to be able to control his/her own behaviors in class as well as examine the behaviors and reactions of his/her students. Teachers' behaviors play a primary role in the personality development of their students.

Overall, this research has revealed the verbal and non-verbal behaviors of teachers toward mentally disabled students in physical education classes. For class management, a variety of mimics and gestures is used functionally and intentionally by the teachers interviewed in this study. Moreover, some teachers stated that they intentionally and functionally use their way of body posture, walking, and sitting in the management of their physical education classes. Moreover, the teachers also stated that they funtionally use the space, distance, and touch aspects in the classroom along with a variety of verbal expressions such as encouraging and advisory statements to achieve more efficient class management. In conclusion, the teachers in Special Education Practice Centers play a key role in fulfilling the goals of physical education classes, on the one hand, and the development of mentally 
disabled students, on the other. Teachers' appropriate verbal expressions and nonverbal behaviors are likely to positively affect the pyschological and educational development of mentally disabled students. This is why the structure of class management which pays attention to the aforementioned verbal and non-verbal behaviors is crucial for positive improvement among mentally disabled students. Thus, the teachers who are interested in developing their skills of class management should be provided with additional training either in their institutions or at universities.

\section{References}

Aydın, A. (2000). Sınıf yönetimi ( Class management), 2. edition, Ankara: Anı Press.

Balkı, E. (2003). Çağdaş sınıf yönetiminde bilişim teknolojileri ve kullanımı (Information technology and practices in contemporary class management), Selçuk University, Institute of Social Sciences, Department of Management and Organization Project of Human Resources Management Program, Konya.

Baş, Ö. (2010). Qualitative research on analysis of verbal expressions and nonverbal behaviours teachers use in classroom, Gazi University, Institute of Education Sciences, Department of Primary Education, Ph.D. Dissertation, pp. 24, 45.

Celep, C. (2002). Sınıf yönetimi ve disiplini (Class management and discipline), Anı Press, Ankara, p. 161.

Çalışkan, N. (2003). Sınıf öğretmenlerinin sözel olmayan iletişim davranışlarının değerlendirilmesi (Evaluation of Non-Verbal Communication Behaviors of Primary Education Teachers), Ph.D. Dissertation, Institute of Social Sciences, Ataturk University, Erzurum.

Çalışkan, N. and Yeşil, R. (2005). The teacher's body language in educational process, Gazi University, Journal of Kirşehir Education Faculty, 6 (1), pp. 205, 206.

Çelik, V. (2002). Sınıf yönetimi (Class management), Ankara: Nobel Press.

Demirel, Ö. (2000). Plandan uygulamaya öğretme sanatı (Art of Teaching from Plan to Practice), Pegem A Press, Ankara.

Erden, M. (2005). Sınıf yönetimi (Class management), Epsilon Press, İstanbul, p. 98.

Ertuğrul, H. (2002). Öğretmenlikte yeni teknikler (New techniques in teaching), İstanbul: Timaş Press, pp. 64, 165.

Gürsel, O. (1993). Zihinsel engelli çocukların doğal sayıları gerçek nesneleri kullanarak eşleme, resimleri işaret ederek gösterme, rakamlar gösterildiğinde söyleme becerilerinin gerçekleştirilmesinde bireyselleştirilmiş öğretim materyalinin basamaklandırılmış yöntemle sunulmasının etkililiği (The efficiency of presentation with an ordered method of personalized teaching material in the realization of speaking abilities when numbers are shown, when pictures are shown by pointing, and when natural numbers are equated with real objects of mentally disabled children), Anadolu University, Institute of Social Sciences, Eskişehir. 
Karabulut, A. and Yıkmış A. (2010). The effectiveness of simultaneous prompting on teaching the skill of telling the time to individuals with mental retardation, Journal of Abant Izzet Baysal University, 10 (2), p. 104.

Marzano, R.J. and Marzano, J.S. (2003). The key to classroom management, Educational Leadership, 61 (1), pp. 6-13.

Ministry of National Education. (2002). Eğitim uygulama okulu eğitim programı (Teaching curriculum of education practice school ), Ankara: National Education Press, Ankara.

Norris, J.A. (2003). Looking at classroom management through a social and emotional learning lens, Theory and Practice, 42 (4), pp. 313-318.

Özyürek, M. (1990). Özel eğitimde teşhis sorunları ve öneriler (Diagnosis of problems and suggestions in private education), First National Congress of Education Sciences, Ankara: Ankara University Education Sciences Faculty Press.

Pektaş, S. (1988). Sözel olmayan öğretmen davranışlarının öğretime etkilerinin değerlendirmesi (Evaluation of the Effects of Non-Verbal Teacher Behaviors on Teaching), $\mathrm{Ph} . \mathrm{D}$. Dissertation, Ankara University, Institute of Social Sciences, Ankara.

Selçuk, Z. (2001). Okul deneyimi ve uygulama- öğretmen ve öğrenci davranışlarının gözlenmesi (School experience and practice: examination of teacher and student behaviors ), Nobel Press, Ankara, 2. edition, p. 64.

Schober, O. (1999). Beden dili (Body language), Translated by: Süeda Özbent, İstanbul: Arion Press, p. 120.

Sucuoğlu, B. (2010). Zihin engelliler ve eğitimleri (The mentally disabled and their education), 3. edition, Ankara: Kök Press, p. 44.

Wragg, E.C. and Wragg, C.M. (1998). Classroom management research in the United Kingdom, Eric Document, Accessed: http://files.eric.ed.gov/fulltext/ED418971.pdf, Access Date: March, 15, 2015.

Yıldırım, A. and Şimşek, H. (2006). Sosyal bilimlerde nitel araştırma yöntemleri (Qualitative research in social sciences), 6. edition, Ankara, Seçkin Press. 